Check for updates

The BMJ

kabbasi@bmi.com Follow Kamran on Twitter@KamranAbbasi Cite this as: BMJ2020;371:m4277 http://dx.doi.org/10.1136/bmj.m4277 Published: 05 November 2020

\title{
The democratic, political, and scientific failures of covid-19
}

\section{Kamran Abbasi executive editor}

Democracy was tested this week. The evidence for the health benefits of democracy is well established, but democracies are being eroded or "autocratised." Presidents and ruling cabals use democracy to gain power and then abuse democracy to retain it. A new study finds that this autocratisation is bad for health. ${ }^{1}$ It might partly explain why many democracies are responding poorly to the coronavirus pandemic. ${ }^{2}$

Accountability and responsibility are also being tested, nowhere more visibly than in the relations between scientists and politicians. Politicians trade on certainty. Often, political conviction is baseless but inspires followers.

Doctors can fall into the same patterns of behaviour, offering treatments with overstated surety. Medicine was beginning to embrace uncertainty, yet the pandemic has provoked politicians and health experts to rely on certainty where little exists. On the imminent arrival of a vaccine, for example, despite ongoing doubt about the timing and value of current trials. ${ }^{3}$ On asymptomatic transmission of covid-19. ${ }^{4}$ On behavioural "fatigue." ${ }^{5}$ On the disturbing blame directed at GPs. ${ }^{6}$

Acknowledging debate and disagreement strengthens a politician's hand, ${ }^{7}$ but only a few are wise enough to see it. Differing viewpoints, from across disciplines and social groups, improve the quality and nuance of scientific advice, but several democracies have shut down debate about their pandemic policies or sought only a narrow caucus of views.

This political bear pit is not a natural home for a professorial chief medical officer. Chris Whitty has the daunting job of providing scientific advice to Boris Johnson's government. In a rare interview, he describes how he navigates the political minefields. ${ }^{8}$ Readers might not agree with where he draws a line between science and politics, or whether such a distinction is possible, but he has a clear view. Whitty is focusing on science, while politicians must also consider social factors and the economy, even though those deliberations, unlike the scientific advice, are seldom revealed.

Whitty is emphatic on the science of the pandemic. On the error of the Great Barrington declaration and other arguments for a population immunity strategy. On eradication as an implausible approach. On the enduring nature of the pandemic. On collective leadership in public health and medicine. On local leadership at the sharp end. On transparency. On his independence. On surviving the bear pit. On hope.

Too many democracies are now relying on lockdowns of last resort to wrench back control of the virus after their failed pandemic response, in the UK's case epitomised by a disastrous test, trace, and isolate programme. ${ }^{9}$ Democracies, politicians, and scientists, then, have much to put right before the next pandemic surge arrives.

1 Wigley S, Dieleman JL, Templin T, Mumford JE, Bollyky TJ. Autocratisation and universal health coverage: synthetic control study. BMJ 2020;371:m4040. doi: 10.1136/bmi.m4040 pmid: 33097492

2 Bollyky TJ, Kickbusch I. Preparing democracies for pandemics. BMJ 2020;371:m4088. doi: 10.1136/bmi.m4088 pmid: 33097482

3 Doshi P. Covid-19 vaccine trial protocols released. BM/2020;371:m4058. doi: 10.1136/bmj.m4058 pmid: 33087395

4 Cevik M, Kuppalli K, Kindrachuk J, Peiris M. Virology, transmission, and pathogenesis of SARS-CoV-2. BMJ 2020;371:m3862 doi: 10.1136/bmi.m3862 pmid: 33097561

5 Michie S, West R, Harvey N. The concept of "fatigue" in tackling covid-1. BMJ Opinion. 26 Oct 2020. https://blogs. bmi.com/bmi/2020/10/26/theconcept-of-fatigue-in-tackling-covid-19.

6 Gerada C. Clare Gerada: GPs-scapegoats and saviours, heroes and villains. BMJ 2020;371:m4187. doi: 10.1136/bmi.m4187 pmid: 33144277

7 Moore A, Mackenzie MK. Policy making during crises: how diversity and disagreement can help manage the politics of expert advice. BMJ 2020;371:m4039. doi: 10.1136/bmj.m4039 pmid: 33106231

8 Godlee F, Mun-Keat L. The BMJ interview: Chris Whitty, England's chief medical officer, on covid-19. BM/2020;371:m4235doi: 10.1136/bmj.m4235.

9 Mahase E. Covid-19: UK government must "get its act together" as modelling suggests 85000 deaths in second wave, experts say. BMJ 2020;371:m4242. doi: 10.1136/bmj.m4242 pmid: 33127605

This article is made freely available for use in accordance with BMJ's website terms and conditions for the duration of the covid-19 pandemic or until otherwise determined by BMJ. You may use, download and print the article for any lawful, non-commercial purpose (including text and data mining) provided that all copyright notices and trade marks are retained. 